This is not the version of record. The full version of De Clercq, Dirk and Belausteguigoitia, Imanol (2020) Coping and laughing in the face of broken promises : implications for creative behavior. Personnel Review, 49(4), pp. 993-1014 is available at https://doi.org/10.1108/PR-11-2018-0441. 
Coping and laughing in the face of broken promises: Implications for creative behavior

Dirk De Clercq

Imanol Belausteguigoitia

Accepted for Personnel Review 


\title{
Coping and laughing in the face of broken promises: Implications for creative behavior
}

\begin{abstract}
Purpose-This article considers how employees' perceptions of psychological contract breach, due to their sense that their organization has not kept its promises, might diminish their creative behavior. Yet access to two critical personal resources - emotion regulation and humor skillsmight buffer this negative relationship.
\end{abstract}

Design/methodology/approach—Survey data were collected from employees in a large organization in the automobile sector.

Findings-Employees' beliefs that their employer has not come through on its promises diminishes their engagement in creative activities. The effect is weaker among employees who can more easily control their emotions and who use humor in difficult situations.

Practical implications-For organizations, the results show that the frustrations that come with a sense of broken promises can be contained more easily to the extent that their employee bases can rely on pertinent personal resources.

Originality/value - This investigation provides a more comprehensive understanding of when perceived contract breach steers employees away from productive work activities, in the form of creativity. This damaging effect is less prominent when employees possess skills that enable them to control negative emotions or can use humor to cope with workplace adversity.

Keywords: perceived contract breach; creative behavior; emotion regulation skills; humor skills; conservation of resources theory

Paper type-Research paper 


\section{Introduction}

When employees operate in adverse, resource-depleting work environments, they exhibit lower work motivation and engage in fewer productive work behaviors (Coelho, Augusto, \& Lages, 2011; Hobfoll \& Shirom, 2000; Jamil, Raja, \& Darr, 2013; Perko, Kinnunen, \& Feldt, 2017). Such workplace adversity might result from the belief that an employer has broken its psychological contract with them-that is, the implicit agreement about the obligations that the employer has toward them (Rayton \& Yalabik, 2014; Robinson \& Rousseau, 1994; Sonnenberg, Koene, \& Paauwe, 2011). A psychological contract breach can become manifest in different ways, such as when employees sense that their employer has not fulfilled promises it made at the time of their recruitment or failed to accommodate needs that employees developed thereafter (Cassar \& Buttigieg, 2015; Robinson \& Morrison, 2000). The experience of broken organizational promises is deeply salient in terms of the hardship that it imposes on employees' psychological well-being, suggesting the need for further studies that detail potentially harmful behavioral responses by employees and tactics for reducing or mitigating these responses (Garcia, Bordia, Restubog, \& Caines, 2018; Phuong, 2016; Restubog, Zagenczyk, Bordia, Bordia, \& Chapman, 2015).

Extant scholarship cites a plethora of negative consequences of employees' beliefs that their organization has failed to keep its promises, including enhanced emotional exhaustion (Lapointe, Vandenberghe, \& Boudrias, 2013), insomnia (Garcia et al., 2018), workplace deviance (Restubog et al., 2015), and turnover intentions (Kraak, Lunardo, Herrbach, \& Durrieu, 2017), as well as reduced psychological well-being (Hill, Morganson, Matthews, \& Atkinson, 2016), organizational commitment (Cassar \& Briner, 2011), job satisfaction (Arain, Hameed, \& Farooq, 2012), trust in the employer (Tomprou, Nikolaou, \& Vakola, 2012), in-role performance 
and organizational citizenship behavior (Suazo \& Stone-Romero, 2011), and career success (Restubog, Bordia, \& Bordia, 2011). With this study, we investigate the harmful effect of employees' perception of broken organizational promises on their propensity to undertake productive work behaviors in the form of creativity. Creative behaviors involve the generation of novel ideas that can add to the organization's well-being and competitive advantage (De Clercq, Rahman, \& Belausteguigoitia, 2017; Oldham \& Cummings, 1996; Shalley \& Gilson, 2004; Tse \& Chiu, 2014). We focus explicitly on these creative behaviors because they tend to be disruptive and shift the functions of the organization, such that other organizational members may express skepticism or even resist novel ideas, particularly if the outcomes make them look bad or undermine their influence (Buchanan \& Badham, 1999; Yuan \& Woodman, 2010). In this sense, creative behaviors already might be somewhat discouraged, so it is particularly important for organizational decision makers to identify additional reasons employees might avoid productive creative activities, namely, due to their frustration about broken organizational promises that leave them with insufficient residual energy to undertake strenuous activities that upset the status quo (Amabile, 1996; Coelho et al., 2011; Hobfoll \& Shirom, 2000).

\section{COR theory}

In addition to being theoretically and managerially important, our focus on creative behaviors is driven by a research gap: Despite a general recognition that employees who blame their employer for not keeping its promises tend to feel frustrated and economize their productive work efforts (Chen, Tsui, \& Zhong, 2008; Rayton \& Yalabik, 2014; Restubog et al., 2015; Suazo \& Stone-Romero, 2011), research that explicitly links employees' perceptions of contract breach with a reluctance to engage in creative behavior is sparse (Agarwal \& Bhargava, 2014). Using conservation of resources (COR) theory (Hobfoll, 1989), we propose that unfavorable 
organizational conditions, such as perceptions of contract breach, tend to deplete employees' energy resource levels, leading them to seek to conserve their existing resource bases when they decide which activities to perform, including creative behaviors (Hobfoll, 2001; Hobfoll \& Shirom, 2000). Our study does not directly measure the specific ways such energy depletion might be manifest, but our logic is based on previous studies that suggest various energydraining mechanisms, resulting from broken organizational promises, that speak to either employees' limited ability to perform productive work activities, such as a sense of reduced job control (Shore \& Tetrick, 1994) and enhanced stress levels (Ng \& Feldman, 2012), or a lack of motivation, as informed by their self-depreciating thoughts (Restubog, Hornsey, Bordia, \& Esposo, 2008) and frustration about disrespectful organizational treatment (Rousseau, 1995). We subsume these different mechanisms under the general umbrella of energy resource losses, while also acknowledging that the manifestations of such losses can be manifold. When employees blame their organization for not keeping its promises, they may lack the stamina or energy resources to engage in energy-consuming creative behaviors, irrespective of the specific form that their energy depletion takes (Lapointe et al., 2013; Suazo \& Stone-Romero, 2011).

Moreover, we follow the logic of COR theory to suggest that the presence of negative behavioral responses depends on whether employees can draw from relevant personal resources to counter resource losses due to contract breaches (Abbas, Raja, Darr, \& Bouckenooghe, 2014; Hobfoll \& Shirom, 2000). Hobfoll (2002, p. 307) broadly defines the term resources as "those entities that either are centrally valued in their own right ... or act as a means to obtain centrally valued ends." Of the various resources that Hobfoll (2001) lists in describing COR theory, two notable examples are a feeling of having control over one's life and a sense of humor. We similarly focus on employees' emotion regulation skills and humor skills as two critical personal 
resources that may buffer employees against the depletion of their energy resource reservoirs, in response to broken psychological contracts (Garcia et al., 2018). That is, including emotion regulation and humor skills as moderators in our proposed conceptual framework aligns with COR theory, because they both allow employees to maintain a certain level of productive work behaviors, despite exposure to resource-depleting disappointment (Garcia et al., 2018; Hobfoll \& Shirom, 2000). Emotion regulation skills enable employees to control their emotions and stay calm in challenging situations (Jiang, Zhang, \& Tjosvold, 2013); humor skills help them cope by using their wit to put the situations into perspective and remain positive despite experienced hardships (José, Parreira, Thorson, \& Allwardt, 2007). ${ }^{1}$

Formally, we predict that the negative relationship between employees' perceptions of contract breach and their creative behavior might be less prominent to the extent that they can draw from these two personal resources, because the resources infuse employees with positive energy that increases their ability and motivation to mitigate the frustration of psychological contract breach (Quinn, Spreitzer, \& Lam, 2012; Restubog et al., 2015). Moreover, the two personal resources complement each other: Emotion regulation skills help employees cope directly with negative emotions, such as frustration and disappointment (Buruck, Dorfel, Kugler, \& Brom, 2016; Gratz \& Roemer, 2004), while humor skills operate more indirectly, helping them remain positive about difficult job situations, because they joke around and communicate with other organizational members, and they exhibit an overall sense of relativism (LehmannWillenbrock \& Allen, 2014; Mesmer-Magnus, Glew, \& Chockalingam, 2012). By investigating these two personal contingencies, we offer a consistent, comprehensive view on how employees' personal resources may reduce the likelihood that they avoid productive work behaviors, in the

\footnotetext{
${ }^{1}$ Cooper, Kong, and Crossley (2018) conceptualize leader humor as an interpersonal resource that helps employees cope with stressful work situations. We similarly conceptualize humor as an intrapersonal resource, not a disposition, from which employees can draw to cope with their perceptions of psychological contract breach.
} 
form of creativity, because they are frustrated by broken organizational promises (Chen et al., 2008; Garcia et al., 2018; Hobfoll, 2001; Restubog, Bordia, \& Tang, 2007).

\section{Contributions}

With this study, we seek to contribute to extant scholarship in several ways. First, we apply COR theory to propose that perceptions of contract breach lead to a depletion of employees' energy resources, prompting reduced creativity. This contribution to extant literature is relevant, because employees who blame their organization for not keeping up its side of the bargain might become so frustrated about their job situation that they refuse to engage in disruptive creative behaviors — which already are energy consuming and might be met with resistance by other organizational members (Yuan \& Woodman, 2010) - that otherwise could contribute to their organization's success (Agarwal \& Bhargava, 2014; Rayton \& Yalabik, 2014; Suazo, 2009). We also predict and test how this relationship might be buffered by two pertinent personal resources that have not been studied in relation to psychological contract perceptions. By explicating the buffering roles of employees' emotion regulation and humor skills, we address calls to apply contingency approaches to the negative outcomes of psychological contract breaches and help clarify when this resource-draining organizational condition is less likely to escalate (Garcia et al., 2018; Phuong, 2016; Priesemuth \& Taylor, 2016; Restubog et al., 2015). We also complement studies of the direct positive roles of emotional competencies (O’Boyle, Humphrey, Pollack, Hawver, \& Story, 2011) or humor (Mesmer-Magnus et al., 2012) for spurring positive work behaviors; that is, we specify that these personal resources have indirect effects and buffer employees' negative reactions to beliefs that their employer has broken its promises (Hobfoll \& Shirom, 2000). Organizations thus can better protect their 
employee bases against the hardship of broken promises, by helping them develop pertinent personal skills.

Furthermore, our study of the combined roles of perceived contract breach and these two personal resources takes place in the understudied empirical setting of Mexico, which represents a contribution. From a general perspective, we address calls for additional studies of adverse organizational conditions in non-U.S. settings (e.g., Arain et al., 2012; Arshad, 2016; Bao, Olson, Parayitam, \& Zhao, 2011; Biswas, 2016). Mexican culture in particular is marked by high levels of uncertainty avoidance (Hofstede, Hofstede, \& Minkov, 2010), so career-related uncertainty evoked by broken organizational promises (Robinson \& Rousseau, 1994) might have a particularly strong negative effect on the quality of employees' daily organizational functioning, which in turn might undermine their propensity to perform disruptive, potentially risky creative behaviors that change the organizational status quo. The high power distance that characterizes Mexican culture also might imply that organizational decision makers are generally willing to break promises that they made in the past (Hofstede et al., 2010), so the risk of contract breaches may be more widespread and shared by many Mexican employees.

Moreover, the two focal moderators of this study - emotion regulation and humor skills - are particularly interesting factors to consider in the context of Mexico, because their hypothesized roles are not straightforward, which makes them particularly compelling in light of this cultural profile. First, its collectivistic nature underscores the importance of group harmony and the free expression of emotions when interacting with other organizational members, so employees may find it appropriate to use emotion-based skills to mitigate hardships they encounter in their daily job functioning (Hofstede et al., 2010; Pooja, De Clercq, \& Belausteguigoitia, 2016). From this perspective, relying on emotion regulation skills represents 
an effective strategy to cope with frustrations due to broken organizational promises. Yet this very sense of comfort that Mexican employees may have in terms of expressing disappointments and negative emotions about unfavorable work circumstances with like-minded peers (Hofstede et al., 2010; Oyserman, Coon, \& Kemmelmeier, 2002) may also imply that they experience less need to rely on such personal skills to control their temper or remain calm in the presence of psychological contract breaches.

Second, the wider cultural context in which employees operate influences the degree to which they use humor when they face adverse, resource-draining work situations (Robert \& Yan, 2007; Wang, Chan, Goh, Penfold, Harper, \& Weltewitz, 2018), but this effect might not be straightforward in Mexico, with its high levels of collectivism. Even if employees may feel comfortable making jokes about an unfavorable work environment marred by broken organizational promises, to share their frustrations and put their collectively adverse job situation into perspective (Hofstede et al., 2010), they also might be fearful that their humor conflicts with cultural norms for conformity, such that they risk being reprimanded for their "daring" humor (Kalliny, Cruthirds, \& Minor, 2006; Robert \& Yan 2007). Taken together, these arguments highlight why Mexico reflects a relevant research context for studying the concurrent roles of employees' perceptions of contract breach, emotion regulation skills, and humor skills to predict their creative behavior.

Figure 1 summarizes our proposed conceptual framework and its underlying hypotheses. We connect employees' perceptions of contract breach with their creative behavior, then predict how this relationship shifts in the presence of two types of skills, emotion regulation and humor, that inform employees' ability and motivation to deal with broken organizational promises. In line with COR theory (Hobfoll, 1989, 2001), we predict that employees' perceptions of contract 
breach reduce their creative behaviors, but this effect is attenuated when they can draw from personal resources.

\section{[Insert Figure 1 about here]}

\section{Hypotheses}

Perceptions of contract breach and creative behavior

The likelihood that employees go out of their way to generate novel ideas for organizational improvement may be thwarted to the extent that they have a sense that their organization has not kept its previously made promises. When employees sense a breach in the psychological contract, they feel less in control of their jobs (Shore \& Tetrick, 1994), and the associated energy depletion undermines their ability to contribute to their organization's success through discretionary (creative) behaviors (Hobfoll, 2001; Ng \& Feldman, 2012). Creative ideas are often disruptive and upsetting to the organizational status quo, so they tend to invoke resistance from colleagues who worry about threats to their personal privileges if the creative ideas were to be implemented (Yuan \& Woodman, 2010; Zhou \& George, 2001). Thus, creative behaviors demand energy and stamina to overcome resistance, but the energy-draining effect of perceived contract breaches does not leave them with sufficient energy resources to adopt such behaviors (Agarwal \& Bhargava, 2014; Lapointe et al., 2013; Quinn et al., 2012). Conversely, when they are unencumbered by negative thoughts about broken promises, employees have more ability to allocate sustained energy to generating novel ideas.

Furthermore, the feelings of disappointment that come with beliefs about broken organizational promises may diminish employees' motivation to generate creative ideas that can benefit their organization (Amabile, 1996). If the organization has not fulfilled its promises to them, employees should be less excited about the possibility of adding to its well-being by 
undertaking strenuous, productive work behaviors such as creativity (Chen et al., 2008; Suazo \& Stone-Romero, 2011). The hardship caused by perceived contract breach undermines employees' self-esteem (Restubog et al., 2008) and signals to them that their organization does not respect their daily work efforts or contributions (Orvis et al., 2008; Restubog et al., 2015; Rousseau, 1995); they accordingly may come to believe it does not deserve their devoted efforts. In contrast, when employees perceive that their employer generally keeps up its side of the employment bargain, they sense more support and respect from the organization (Zagencyk, Gibney, Few, \& Scott, 2011), so they should be more enthusiastic about their potential contributions to organizational well-being, through their discretionary, creative behaviors.

Hypothesis 1: There is a negative relationship between employees' perceptions of contract breach and their creative behavior.

\section{Moderating role of emotion regulation skills}

This negative relationship should be buffered by emotion regulation skills. According to COR theory, the resource-draining effect of unfavorable organizational settings can be mitigated to the extent that employees can counter the resource losses by relying on their pertinent personal resources (Hobfoll, 1989, 2001). Employees equipped with emotion regulation skills can better manage the frustration that results from their sense that their organization has not kept its promises, because they are able to contain the negative energy that results from this negative work situation (Gratz \& Roemer, 2004; Jiang et al., 2013). In turn, they retain some residual energy to engage in productive work behaviors, such as creativity (Parke, Seo, \& Sherf, 2015; Quinn et al., 2012). Prior research shows that employees with strong emotion regulation skills use more successful coping strategies when they experience unfavorable work circumstances, compared with colleagues who lack such skills (Buruck et al. 2016; Eisenberg \& Farbes, 1992; 
Gross, 1998). Even if they believe that their organization has failed them, by not keeping its previously made promises, emotionally skilled employees can protect themselves against this hardship (Cassar \& Briner, 2011; Robinson \& Morrison, 2000), so their ability to allocate significant energy resources to productive creative activities remains intact (Amabile, 1996).

Emotionally skilled employees also can adjust more successfully to adverse organizational conditions, by empathizing with organizational decision makers (Jiang et al., 2013) and understanding that they might have had no other choice than to break certain promises, due to unforeseen external changes or pressures, for example (Robinson \& Morrison, 2000). With such empathy, emotionally skilled employees can keep their frustrations from escalating into a reluctance to engage in productive behaviors (Hobfoll \& Shirom, 2000). Furthermore, employees with a better grasp on their own emotions may enjoy finding creative ways to perform effectively in the face of organizational adversity, because it gives them a sense of personal achievement. Thus, they might even appreciate an adverse work situation marked by a contract breach for giving them the opportunity to demonstrate their ability to identify and implement novel solutions to the problem (Biron \& van Veldhoven, 2012; Ryan \& Deci, 2000; Sy, Tram, \& O’Hara, 2006). Employees' emotion regulation skills thus should serve as buffers that prevent a perception of broken organizational promises from translating into reduced creative activities.

Hypothesis 2: The negative relationship between employees' perceptions of contract breach and their creative behavior is moderated by their emotion regulation skills, such that the relationship is weaker among employees with stronger emotion regulation skills.

\section{Moderating role of humor skills}

The translation of perceived contract breach into reduced creative behavior also should be mitigated by employees' humor skills. Employees who use humor to deal with difficult work 
situations tend to be more communicative and discuss the situations with their colleagues, perhaps by joking about them (Lehmann-Willenbrock \& Allen, 2014; Pouthier, 2017). Even if humorous, such communication enhances the colleagues' knowledge exchange, which can grant employees deeper insight into and appreciation for why it might be impossible for their employer to keep its previously made promises (Robinson \& Morrison, 2000). Thus, the additional insights gained from their interactions with peers, who also tend to be more willing to share their own experiences with people who have a good sense of humor (Pouthier, 2017; Smith \& Khojasteh, 2014), should diminish employees' reluctance to undertake positive creative behaviors in the presence of resource-depleting contract breaches, because they come to understand why their employer might not have fulfilled certain promises (Hobfoll \& Shirom, 2000).

Moreover, employees confronted with a perceived contract breach can rely on their humor to undo the negative situation, such as by using their wit to influence organizational decision makers to reconsider their treatment of employees (Romero \& Cruthirds, 2006). Employees who cannot draw from humor skills instead might get overwhelmed by negative ruminations and anger about this negative aspect of their job situation (Arain et al., 2012; Restubog et al., 2007), which would diminish their willingness to undertake productive, creative behaviors. Finally, mirroring the case of emotion regulation skills, employees with the ability to use humor to deal with adversity might be enticed by the opportunity to identify solutions to the contract breach (Lyttle, 2007; Romero \& Cruthirds, 2006) and experience a sense of personal fulfillment if they are able to come up with novel ideas that reverse a resource-draining situation in which their employer fails to keep its promises (Hobfoll \& Shirom, 2000). Thus, humor as a personal resource might spur employees' motivation to counteract the anticipated negative outcomes of broken organizational promises by finding creative solutions (Amabile, 1996; Ryan 
$\&$ Deci, 2000), and such efforts may counter the energy-depleting effect of perceived contract breach.

Hypothesis 3: The negative relationship between employees' perceptions of contract breach and their creative behavior is moderated by their humor skills, such that the relationship is weaker among employees with more humor skills.

\section{Research method}

\section{Sample and data collection}

To test the research hypotheses, we collected data from employees in a large Mexicanbased organization that produces automobile parts and accessories. This sector is marked by high levels of competition, so the studied organization constantly seeks to stimulate and implement creative ideas. The external competitive pressures that the organization faces also require it to remain flexible and open to change in terms of how it operates internally; it is not unlikely then that some employees may have experienced a situation in which the organization did not keep its previously made promises to them. Thus, questions of why and when some employees might be less likely to carry out creative behaviors, as a negative response to the frustration invoked by contract breaches, are highly pertinent for this organization. Furthermore, different organizations face unique external challenges that affect the urgency of employees' creative behaviors (Dayan \& Di Benedetto, 2011), so our focus on a single organization reduces the potential influence of such unobserved differences.

For the data collection, we relied on a survey instrument, administered as a paper-andpencil version. A preliminary version was pretested with a small set of employees who did not participate in the actual data collection. Their feedback helped improve the readability of the questions and data quality. The survey questions were originally prepared in English and then translated into Spanish by a bilingual translator. To guarantee the quality of the translation, avoid 
cultural bias, and detect any discrepancies, this Spanish version was back-translated into English by another bilingual translator (Brislin, Lonner, \& Thorndike 1973). Some minor changes appeared in the final version of the survey, administered in Spanish.

Participants were assured complete confidentiality and informed that only the researchers would ever have access to their individual responses. We also encouraged participants to answer the questions as honestly as possible, assured them repeatedly that there were no right or wrong answers, and noted that it was natural for employees to provide varying scores. These efforts and reassurances minimize the possibility of social desirability, acquiescence, or common method biases (Conway \& Lance, 2010; Spector, 2006).

We distributed 250 surveys to a random selection of employees, obtained from an employee list provided by the organization's human resource department. This random selection ensured that a broad section of employees could participate in the survey, spanning employees whose responsibilities related directly to the manufacturing process and those focused more on support activities, as well as employees operating at different levels of the organization. ${ }^{2} \mathrm{~A}$ comparison of early and late respondents did not reveal any significant differences in the focal variables, thus diminishing concerns about response bias (Armstrong \& Overton, 1977). Our final sample consisted of $40 \%$ women, and the average tenure with the organization was 3 years; furthermore, $34 \%$ of the sample had supervisory responsibilities over other employees.

\section{Measures}

The measures of all four focal constructs came from previous research, assessed with seven-point Likert scales ( 1 = strongly disagree, 7 = strongly agree $)$.

\footnotetext{
${ }^{2}$ The survey did not explicitly ask for employees' job function, but a specific question gauged their job level, distinguishing employees who had no supervisory responsibilities at all (lower level), those with some supervisory responsibilities (middle level), and those who had a say in the organization's strategic decisions (upper level).
} 
Creative behavior. We measured the extent to which employees engage in creative behavior with a three-item scale based on previous studies (De Clercq et al., 2017; Janssen, 2001). For example, employees indicated whether "I often create new ideas for improvement" and "I often generate original solutions to problems" (Cronbach's alpha $=.92)$. Supervisorprovided ratings might diminish common method bias concerns, yet self-rated assessments of creativity are common (e.g., Kaufman \& Baer, 2004; Shalley, Gilson, \& Blum, 2009) and arguably even preferable, because other organizational members, including supervisors, typically cannot observe the total range of creative activities that employees engage in, so self-perceived measures provide more comprehensive insights (Hocevar, 1981; Zhou, Shin, \& Cannella, 2008). Similarly, productive work behaviors, such as creativity, are goal-focused and intentional (Shalley, 1991), so their assessment by employees themselves, who are aware of how much time they actually allocate to these behaviors (Janssen, 2000; Lumsden, 1999), has great value.

Finally, when self-rated measured are appropriate and recommended, concerns about the use of a common respondent are mitigated too (Conway \& Lance, 2010).

Perceptions of contract breach. To measure employees' beliefs about broken organizational promises, we applied four items, based on previous research on perceived contract breach (Raja, Johns, \& Ntalianis, 2004; Robinson \& Morrison, 2000). ${ }^{3}$ Two sample statements are "I feel that my employer has come through in fulfilling the promises made to me when I was hired" and "I have received everything promised to me in exchange for my contributions" (Cronbach's alpha $=.93)$.

\footnotetext{
${ }^{3}$ The original scale contained five items (Robinson \& Morrison, 2000), but one item ("My employer has not broken any of its promises for me") was not included in the survey for this study. This specific item is somewhat redundant with the other scale items, and its use of the word "any" arguably makes the wording extreme, such that employees' responses might have suffered from low validity. Although we acknowledge arguments for using the original fiveitem scale, the results are unlikely to differ substantially due to its omission. Moreover, we confirm the convergent validity of the four-item measure, according to the average variance extracted value of .76, greater than the suggested cut-off value of .50, and the significant factor loadings $(p<.001)$ of its constitutive items (Bagozzi \& Yi, 1988; Gerbing \& Anderson, 1988).
} 
Emotion regulation skills. To assess employees' ability to control their emotions, we used a four-item scale of emotion regulation capabilities, based on Jiang and colleagues (2013). For example, the respondents indicated whether "I have good control of my own emotions" and "I can always calm down quickly when I am very angry" (Cronbach's alpha $=.88$ ).

Humor skills. To gauge employees' reliance on humor in the presence of difficult situations, we drew from the Multidimensional Sense of Humor Scale (Thorson \& Powell, 1993) and particularly its four-item adaptive humor subscale, which has been validated by José and colleagues (2007) as effective for capturing employees' ability to cope with workplace adversity. Two example items are "The use of wit helps me master difficult situations" and "The use of humor helps to put me at ease" (Cronbach's alpha $=.88)$.

Control variables. We included three control variables in our models—gender $(1=$ female), organizational tenure ( $1=$ less than 1 year, $2=1-2$ years, $3=3-5$ years, $4=6-10$ years, $5=11-20$ years, and $6=$ more than 20 years $)$, and job level $(1=$ lower level, $2=$ middle level, 3 $=$ upper level) — to account for alternative possible explanations of employees' engagement in creative behaviors. We included gender because it can influence the likelihood that employees engage in creative behaviors (Baer \& Kaufman, 2008). We also controlled for employees' organizational tenure and job level; people who have worked for their employer for a longer time or who have more job responsibilities likely have more latitude to undertake creative behaviors, as well as more confidence that their novel ideas have value for the organization and will not be met with excessive skepticism or resistance (Bandura, 1997; Gong, Huang, \& Farh, 2009).

We checked the validity of the focal constructs by estimating a four-factor model with confirmatory factor analysis (Anderson \& Gerbing, 1988). This model achieved very good fit: $\chi^{2}(84)=120.57$, incremental fit index $=.98$, Tucker-Lewis index $=.97$, confirmatory fit index $=$ 
.98 , and root mean squared error of approximation $=.05$. The average variance extracted values for each construct were greater than .50 , and the factor loadings of all items on their respective constructs were strongly significant $(p<.001)$, which indicates the presence of convergent validity (Bagozzi \& Yi, 1988; Gerbing \& Anderson, 1988). To establish evidence of discriminant validity, we compared the fit of constrained models, in which the correlation between two constructs was set to 1 , with that of their unconstrained counterparts, in which the correlations were free to vary. For each of six pairs of constructs, the unconstrained models showed superior fit $\left(\Delta \chi^{2}(1)>3.84, p<.05\right)$, in support of the presence of discriminant validity (Anderson \& Gerbing, 1988).

We performed two statistical tests to address possible concerns about common method bias. First, with Harman's one-factor test (Podsakoff \& Organ, 1986), we checked whether a single-factor model that included all four constructs - creative behavior, perceptions of contract breach, emotion regulation skills, and humor skills — might be responsible for a majority of the total variance in the data. The first extracted factor explained only $34 \%$ of the variance, which mitigated concerns about our use of a common respondent. Second, we undertook a confirmatory factor analysis in which we compared the fit of the aforementioned four-factor model with that of a one-factor model in which each item loaded on a single factor. The former model had a superior fit $\left(\Delta \chi^{2}(6)=1,180.80, p<.001\right)$, which further diminished concerns about common method bias (Lattin, Carroll, \& Green, 2003). Common method bias also tends to be less of an issue for conceptual models that include moderating effects, because it is difficult for research participants to foresee these effects and adjust their responses accordingly (Brockner, Siegel, Daly, Tyler, \& Martin, 1997; Simons \& Peterson 2000).

\section{Results}


Table 1 shows the zero-order correlations and descriptive statistics, and Table 2 contains the regression results. Model 1 included the control variables, Model 2 added perceived contract breach and the two personal resources, and Models 3-4 added the two interaction terms: perceptions of contract breach $\times$ emotion regulation skills and perceptions of contract breach $\times$ humor skills. Previous recommendations suggest adding multiple interaction terms in separate equations, because their simultaneous inclusion in one model can hide true moderating effects (Aiken \& West, 1991; Covin, Green, \& Slevin, 2006; De Clercq \& Belausteguigoitia, 2017; Zahra \& Hayton 2008). Following Aiken and West (1991), we mean-centered the variables before calculating the product terms.

[Insert Tables 1 and 2 about here]

Consistent with the basic premise of this study that the frustration caused by a sense of broken organizational promises might turn employees away from energy-consuming creative activities, Model 2 shows that perceptions of contract breach relate negatively to creative behavior $(\beta=-.09, p<.05)$, in support of Hypothesis 1 . We also note some results that we did not predict, because they fall outside the scope of our conceptual focus: Emotion regulation skills $(\beta=.32, p<.001)$ and humor skills $(\beta=.12, p<.05)$ both exhibit direct, positive relationships with creative behavior.

Models 3-4 issue support for the hypothesized buffering effects of emotion regulation skills $(\beta=.12, p<.01)$ and humor skills $(\beta=.09, p<.01)$ on the relationship between perceptions of contract breach and creative behavior. The likelihood that employees' increasing beliefs about unmet expectations compromise their engagement in creative behavior is lower to the extent that they can draw from their emotion regulation skills (Hypothesis 2) and humor skills (Hypothesis 3). As Figures 2 and 3 and the corresponding simple slope analyses show 
(Aiken \& West, 1991), the relationship between perceptions of contract breach and creative behavior is negative and significant when emotion regulation skills $(\beta=-.21, p<.001)$ and humor skills $(\beta=-.16, p<.01)$ are low, then becomes not significant at high levels of the two personal resources $(\beta=.03, n s ; \beta=.02, n s$, respectively), in support of Hypotheses 2 and 3 , as well as our overall theoretical framework.

[Insert Figures 2 and 3 about here]

Although the theoretical focus for this cross-sectional study was the concurrent interplay of perceptions of contract breach, emotion regulation skills, and humor skills for predicting creative behavior, we also undertook a post hoc analysis to account for potential interdependencies among the three predictors. For example, employees' perceptions of contract breach might be influenced by their own skill levels. Accordingly, we tested two path models, corresponding to the two-regression Models 3-4 in Table 2, that included the covariances among perceptions of contract breach, emotion regulation skills, and humor skills. The hypothesized effects remain consistent with the results of our regression analysis (Table 2): The main effect of perceptions of contract breach and the moderating effects of the two personal resources are robust even when we account for possible causal interdependencies (De Clercq, Thongpapanl, \& Dimov, 2009). We also checked an alternative model, in which perceptions of contract breach functioned as a potential mediator, but failed to find empirical support for this mediation. The bootstrapped confidence intervals for the indirect effects of emotion regulation skills and humor skills on creative behavior, through perceptions of contract breach, include zero, indicating the lack of any mediation (Preacher \& Hayes, 2004).

\section{Discussion}


To contribute to extant literature, this study focuses on two personal resources, emotion regulation skills and humor skills, that hitherto have been unexplored as potential buffers of the likelihood that employees' perceptions of contract breach might diminish their creative behaviors (Robinson \& Morrison, 2000). The scant prior attention to these two energy-enhancing resources is somewhat surprising, because the energy depletion resulting from beliefs about psychological contract breach can be overcome by employees' access to them (Chen et al., 2008; Orvis et al., 2008; Phuong, 2016). Using COR theory as a conceptual basis (Hobfoll, 1989, 2001), we accordingly have addressed unexplored issues related to how and when perceptions of psychological contract breaches might escalate into negative behavioral responses. Our conceptual focus on the buffering effects of the two personal resources underscores the incremental role that beliefs about unmet employer obligations might play in turning employees away from creative, productive work behaviors; in turn, organizations can acquire a better understanding of the individual circumstances in which the frustration caused by a sense of organizational betrayal might compromise employees' dedicated creative efforts.

The direct negative relationship between perceptions of contract breach and creative behavior aligns with findings in prior research regarding the detrimental behavioral outcomes of employees' disappointment with their psychological contract, such as their reduced in-role job performance or organizational citizenship behavior (Chen et al., 2008; Restubog et al., 2007; Suazo \& Stone-Romero, 2011) and higher counterproductive work behavior (Restubog et al., 2007, 2015). Perceptions of broken organizational promises likely hinder creative behaviors due to the resource depletion that employees experience when their organization fails to meet their expectations (Lapointe et al., 2013; Orvis et al., 2008). In this situation, employees tend to focus their efforts on easy work activities first, rather than generating disruptive ideas that might usurp 
significant energy and spark resistance among organizational members threatened by such changes (Yuan \& Woodman, 2010). The negative relationship between perceptions of contract breach and creative behavior also likely stems from employees' limited motivation to go out of their way to help an organization that breaks its promises to them (Amabile, 1996; Suazo \& Stone-Romero, 2011). Disappointment or even anger, in response to perceived contract breach, reduces employees' willingness to devote significant energy to positive work activities such as creativity.

Consistent with COR theory though, we show that the resource-draining effect of unfavorable organizational treatments on the propensity to undertake energy-consuming creative behaviors is muted when employees have access to personal resources that can prevent their further resource losses (Hobfoll, 2001). Employees who can more easily control their negative emotions can avoid the emotionally draining disappointments associated with broken organizational promises, because they cope with and adjust to this situation more easily (Buruck et al. 2016; Jiang et al., 2013). This easier adjustment may leave them with residual energy to devote to discretionary creative activities, even in the presence of perceived contract breach (Quinn et al., 2012). Emotionally skilled employees may also derive personal satisfaction from proactively seeking and finding creative solutions to the problem of perceived contract breach (Biron \& van Veldhoven, 2012; Ryan \& Deci, 2000), and this motivational force counteracts a tendency to avoid energy-consuming, creative activities. Employees who lack such emotion regulation resources instead are both less able and less motivated to pursue productive, creative activities when they sense broken organizational promises, so their negative behavioral responses in the form of reduced creative behaviors are more likely to emerge (Hobfoll, 2001). 
Employees' humor skills similarly serve as buffers against the resource-draining effects of broken organizational promises. Enhanced peer communication, through the use of humor in interpersonal exchanges (Lehmann-Willenbrock \& Allen, 2014), may encourage employees to share knowledge about how to find time and energy for productive creative activities, even in the presence of energy-consuming frustrations about broken promises (Hobfoll \& Shirom, 2000). Further, the sense of relativism exhibited by people with a good sense of humor could make them more forgiving of an employer that might not have been able to keep all its promises (Mesmer-Magnus et al., 2012). The insights that arise from their use of wit while interacting with organizational decision makers also might enable them to reverse the negative organizational treatment (Romero \& Cruthirds, 2006). Finally, employees' humor skills might motivate them to find creative solutions to broken organizational promises, such that the sense of personal fulfillment compensates for the energy-draining effect of this adverse work condition (Lyttle, 2007).

Importantly, the moderating effects that we find pertain to the buffering roles of two critical personal resources (emotional regulation and humor skills), so they help explain the incremental contribution of employees' perceptions of contract breach to their diminished creative behavior. For organizational decision makers, these findings therefore reveal that a sense of broken organizational promises has the potential to thwart employees' propensity to go out of their way to develop new ideas for organizational improvement, and we specify the personal circumstances in which this process is more likely to occur. From an empirical perspective, this issue comes to the fore in the slope differences in Figures 2-3, at different levels of the personal resources. The simple slope analyses show that increasing levels of perceived contract breach steer employees away from undertaking creative behaviors when employees cannot draw from 
pertinent resources that could otherwise help them overcome the associated energy depletion. But this outcome does not result when they are endowed with substantial emotion regulation and humor skills. Employees who feel frustrated by unmet expectations lack the ability or motivation to engage in disruptive creative behaviors, which might be met with resistance by other members, but this logic is only valid to the extent that they are deprived of valuable personal resources that could help them deal with the associated hardships.

The finding of this indirect value of two pertinent personal resources — originating from an enhanced ability to control and regulate one's own emotions (Jiang et al., 2013) or to use humor to stay positive when experiencing work-related hardships (José et al., 2007)—also complements previous studies that reveal the buffering roles of other personal factors in mitigating the harm caused by perceived contract breach in diminishing productive work activities. For example, beliefs about broken organizational promises translate into diminished negative work outcomes to a lesser extent among employees who are marked by forgiveness cognition (Costa \& Neves, 2017) or an internal locus of control (Phuong, 2016). Moreover, this study sheds additional light on a possible dark side of employee creativity: Employees who develop new ideas for organizational improvement may encounter significant resistance in their immediate work environment (Yuan \& Woodman, 2010; Zhou \& George, 2001). That is, the negative relationship between perceived contract breach and creative behavior is significant when employees do not have the stamina or motivation to overcome resistance to their creative behavior, in that they already are frustrated by broken organizational promises. Only when employees can draw from valuable energy-enhancing resources (emotion regulation or humor) that help them cope with their disappointment with psychological contract breaches might they 
be willing to ignore the risk that their energy-consuming, novel idea development could be in vain.

Overall, these results thus provide a more comprehensive view of when perceptions of contract breach diminish the likelihood that employees undertake creative activities, as well as which skills enable them to avoid this influence. Our findings extend previous research by revealing an underexplored, negative outcome of beliefs about broken promises (reduced creative behavior) and focusing on the indirect benefits of emotion-based competencies and humor for buffering the translation of such beliefs into reduced creativity, instead of their direct roles in spurring positive work behaviors (Mesmer-Magnus et al., 2012; O’Boyle et al., 2011).

\section{Limitations and future research}

Some limitations of this study provide opportunities for further research. Although the hypotheses were grounded in the well-established COR theory-which predicts a causal effect of exposure to resource-depleting organizational conditions on employees' energy-consuming work activities (Hobfoll, 2001; Hobfoll \& Shirom, 2000)—our analyses relied on cross-sectional data, which creates a possibility of reverse causality. The insights gained from successful creative behaviors arguably may enable employees to influence their work settings and avoid situations in which they cannot meet previously set work goals; further studies accordingly could apply longitudinal designs to establish a more rigorous causal link between perceived contract breach and creativity, as well as specify the contingency conditions that influence this process. ${ }^{4}$ In addition to time lags between the theorized cause and effect, it would be useful to perform laboratory or field experiments that assess the focal variables at multiple points in time and

\footnotetext{
${ }^{4}$ If reverse causality were at play in this study - that is, creative behavior leads to lower perceptions of contract breach - we might expect the two focal personal resources to moderate the relationship between creative behavior and perceptions of contract breach. A post hoc analysis rejects this outcome, which mitigates some concern about the presence of reverse causality.
} 
estimate cross-lagged effects, to establish the causal nature of the hypothesized relationships formally. Such studies also could investigate whether the negative behavioral consequences of psychological contract breach might be more pronounced to the extent that the breach is preceded by more breaches, compared with a scenario in which employees face their first breach.

In a related vein, we theorized that both ability and motivation inform the relationship between perceptions of contract breach and reduced creative behavior, but we did not measure these mechanisms directly. Thus, a notable weakness of this study is that we did not include any mediating variables and theorized that the mechanisms underlying the relationship between perceived contract breach and creative behavior pertain to energy resource depletion in general (Hobfoll \& Shirom, 2000). Continued studies with longitudinal designs could address these issues and investigate, for example, whether the mechanisms involving reduced ability (e.g., lower job control, higher stress) or reduced motivation (e.g., lower self-esteem, being offended by disrespectful organizational treatment) are more salient.

Further, we focus on the buffering roles of two specific personal resources and ignore alternative individual characteristics that might provide additional buffers. For example, the extent to which employees are resilient and bounce back from failures (Stephens, Heaphy, Carmeli, Spreitzer, \& Dutton, 2013) or are passionate about going to work (Baum \& Locke, 2004) might enable them to cope with the frustrations that result from beliefs about broken organizational promises, leaving them with sufficient energy and motivation to engage in productive, creative behaviors. Continued research also could test for potential resource gain spirals (Hobfoll, 2001) or synergistic effects among these different personal resourcesincluding both our focal personal resources and the alternative resources — by which the escalation of psychological contract breaches into diminished creativity would be even less likely 
if employees were equipped with high levels of combinations of these pertinent individual characteristics. ${ }^{5}$ Moreover, contextual factors might have buffering roles, such as employees' trust in the benevolence of their organization's top management (Mahajan, Bishop, \& Scott, 2012), their experience of goal congruence (Vancouver \& Schmitt, 1991), or their reliance on ombudsmen who independently process complaints about broken promises by organizational authorities (Harrison, Hopeck, Desrayaud, \& Imboden, 2013). Another related extension might investigate if employees who face broken organizational promises take particular offense, such that they refuse to engage in creative behaviors, when organizational decision makers themselves use humor or make light of these breaches.

Our focus on the specific outcome of creative behavior was informed by the argument that energy depletion due to broken organizational promises can be particularly detrimental for disruptive, energy-consuming creative behaviors, such that personal resources likely have a particularly pertinent role in explaining the connection between psychological contract breaches and these behaviors. But other behaviors could be considered as well. For example, it would be interesting to investigate how the interplay of perceived contract breach and personal resources influence the extent to which employees voice their opinions about problems (prohibitive voice) or offer solutions (promotive voice) (Liang, Farh, \& Farh, 2012). Continued research could also test whether the harmful effect of perceived contract breach might be more prominent in the case of creative behaviors that are radical in nature versus those that imply only incremental changes to the organizational status quo (Fischer et al., 2014).

As an empirical weakness, we focus on one specific organization in one specific industry, which might limit the generalizability of the findings. Our theoretical arguments are not specific

\footnotetext{
${ }^{5}$ A post hoc analysis revealed no such synergistic effects for the combination of emotion regulation and humour skills in this study though; that is, the three-way interaction term of perceptions of contract breach $\times$ emotion regulation skills $\times$ humour skills is not significant for predicting creative behaviour $(\beta=-.01, n s)$.
} 
to the industry, yet continued studies with a wider set of organizations, operating in different industries, could assess whether varying levels of market turbulence or competitive rivalry stimulate employees to contribute to organizational effectiveness with their creative behaviors, despite the resource-draining frustrations evoked by broken promises (Lahiri, Pérez-Nordtvedt, \& Renn, 2008; Porter, 1996).

Finally, as we noted, the cultural context of Mexico, with its high levels of uncertainty avoidance and power distance (Hofstede et al., 2010), is highly relevant for investigating how personal resources mitigate the threat of uncertainty-enhancing work conditions imposed by organizational authorities. It also constitutes a compelling research setting because its cultural profile means that the theorized moderating effect relationships, even though anchored in the well-established COR theory, are not automatic. That is, the strong focus on peer interactions in this culture might make the reliance on individual emotion regulation skills less necessary (Oyserman et al., 2002) and its focus on group harmony could make a reliance on humor skills less acceptable (Kalliny et al., 2006). In this sense, this study provides a conservative test of the hypotheses. Still, the inclusion of a single country limits the generalizability of the results, and cross-country comparisons could elucidate whether and how energy depletion due to a sense of broken organizational promises explains the likelihood that employees avoid creative behaviors, as well as the roles that distinct contingency factors play in this process, across various cultures.

\section{Practical implications}

This investigation of the joint effects of employees' perceptions of contract breach and relevant personal skills on their creative behaviors offers guidance for managerial practice. When employees experience frustration and blame their employer for not keeping its word, they suffer negative energy repercussions and often lack the stamina or motivation to contribute to their 
organization's success through dedicated creative efforts. Organizations must go out of their way to prevent such negative beliefs from developing among employees. In general, they should avoid breaking their promises. But in some cases, it might be impossible for organizations to keep all their promises, due to unforeseen internal changes or external competitive circumstances (Porter, 1996; Robinson \& Rousseau, 1994). For these organizations, employees who can control their negative emotions or effectively use humor are a great human resource, because they can cope with the frustration created by broken organizational promises.

Detecting employees' disappointment over broken organizational promises might be difficult; they might hide their true feelings to avoid appearing "whiny" or making the current work situation even worse (Robinson \& Morrison, 2000). Therefore, it is up to the organization to identify any negative feelings that employees might have about unmet expectations, then resolve the sources of these disappointments. For example, leaders should be transparent about their decision making and explain why certain psychological contracts might need to be reconsidered, in response to unexpected external trends or pressures. Organizations also could offer tailored training programs to show employees how they can still achieve their work goals, particularly if they must break promises or need employees to adjust their job approaches.

In combination with these types of training, organizations should help employees develop their emotion regulation and humor skills. For example, to spur emotion regulation skills, organizations might nurture emotional competencies that employees can use to cope with unexpected changes to their current work conditions (Jiang et al., 2013). To leverage their humor skills, organizations could underscore the value of maintaining a healthy dose of relativism, putting disappointments into perspective, and reserving some minimum level of positive energy to channel into productive activities, even in unfavorable circumstances (Romero \& Cruthirds, 
2006). In conjunction with these training initiatives, organizations should recognize and reward employees who devote significant energy to positive work behaviors such as creativity, even when their work circumstances are not ideal or deviate from previously made agreements (Quinn et al., 2012). Overall, any measure that enriches employees' skills for controlling their emotions or applying humor should be especially valuable in work situations in which some broken promises are inevitable. Employees endowed with these skills can apply more effective coping strategies to manage the associated hardship and frustration.

\section{Conclusion}

With this study, we have extended research on psychological contracts by investigating how and when employees' perceptions of contract breach might compromise their efforts to undertake creative activities. The likelihood that employees' frustrations due to a sense of broken organizational promises escalate into a reduced propensity to perform these activities diminishes to the extent that they can rely on relevant emotion regulation and humor skills. These personal resources enhance employees' ability and motivation to generate novel ideas from which their organization can benefit, even in the presence of beliefs that their organization has not met its obligations. We hope this study serves as a catalyst for continued studies of how organizations can reduce the risk that negative feelings, in response to breached psychological contracts, steer employees away from productive work behaviors that contribute to organizational effectiveness. 


\section{References}

Abbas, M., Raja, U., Darr, W., and Bouckenooghe, D. (2014). Combined effects of perceived politics and psychological capital on job satisfaction, turnover intentions, and performance. Journal of Management, 40, 1813-1830.

Agarwal, U.A., \& Bhargava, S. (2014). The role of social exchange on work outcomes: a study of Indian managers. International Journal of Human Resource Management, 25, 1484-1504.

Aiken, L.S., and West, S.G. (1991). Multiple regression: Testing and interpreting interactions. Newbury Park, CA: Sage.

Amabile, T.M. (1996). Creativity in context. Boulder, CO: Westview.

Anderson, J.C., \& Gerbing, D.W. (1988). Structural equation modeling in practice: A review and recommended two-step approach. Psychology Bulletin, 1033, 411-423.

Arain, G.A., Hameed, I., \& Farooq, O. (2012). Integrating workplace affect with psychological contract breach and employees' attitudes. Global Business and Organizational Excellence, $31,50-62$.

Armstrong, J.S., \& Overton, T. (1977). Estimating non-response bias in mail surveys. Journal of Marketing 51, 71-86.

Arshad, R. (2016). Psychological contract violation and turnover intention: do cultural values matter? Journal of Managerial Psychology, 31, 251-264.

Baer, J., \& Kaufman, J.C. (2008). Gender differences in creativity. Journal of Creative Behavior, 42, 75-105.

Bagozzi, R.P., \& Yi, Y. (1988). On the evaluation of structural equation models. Journal of the Academy of Marketing Science, 16, 74-94.

Bandura, A. (1997). Self-efficacy: The exercise of control. New York: W. H. Freeman.

Bao, Y., Olson, B., Parayitam, S., \& Zhao, S. (2011). The effects of psychological contract violation on Chinese executives. International Journal of Human Resource Management, 22, 3373-3392.

Baum, J.R., and Locke, E.A. (2004). The relationship of entrepreneurial traits, skill, and motivation to subsequent venture growth. Journal of Applied Psychology, 89, 587-598.

Biron, M., \& van Veldhoven, M. (2012). Emotional labour in service work: psychological flexibility and emotion regulation. Human Relations, 65, 1259-1282.

Biswas, S. (2016). Behavioral and attitudinal outcomes of psychological contract violation. Journal of Management Development, 35, 261-279.

Brislin, R.W., Lonner, W., \& Thorndike, R.M. (1973). Cross-cultural research methods. New York: John Wiley \& Sons.

Brockner, J., Siegel, P. A., Daly, J. P., Tyler, T., \& Martin, C. (1997). When trust matters: The moderating effect of outcome favourability. Administrative Science Quarterly, 42, 558-583.

Buchanan, D., \& Badham, R. (1999). Politics and organizational change: The lived experience. Human Relations, 52(5), 609-629.

Buruck, G., Dörfel, D., Kugler, J., \& Brom, S.S. (2016). Enhancing well-being at work: The role of emotion regulation skills as personal resources. Journal of Occupational Health Psychology, 21, 480-493.

Cassar, V., \& Briner, R.B. (2011). The relationship between psychological contract breach and organizational commitment: Exchange imbalance as a moderator of the mediating role of violation. Journal of Vocational Behavior, 78, 283- 289. 
Cassar, V., \& Buttigieg, S.C. (2015). Psychological contract breach, organizational justice and emotional well-being. Personnel Review, 44, 217-235.

Chen, Z.X., Tsui, A.S., \& Zhong, L. (2008). Reactions to psychological contract breach: a dual perspective. Journal of Organizational Behavior, 29, 527-548.

Coelho, F., Augusto, M., \& Lages, L.F. (2011). Contextual factors and the creativity of frontline employees: The mediating effects of role stress and intrinsic motivation. Journal of Retailing, 87, 31-45.

Conway, J.M., \& Lance, C.E. (2010). What reviewers should expect from authors regarding common method bias in organizational research. Journal of Business Psychology, 25: 325334.

Cooper, C., Kong, D.T., \& Crossley, C. (2018). Leader humor as an interpersonal resource: Integrating three theoretical perspectives. Academy of Management Journal, 61, 769-796.

Costa, S.P., \& Neves, P. (2017). Forgiving is good for health and performance: How forgiveness helps individuals cope with the psychological contract breach. Journal of Vocational Behavior, 100, 124-136.

Covin, J.G., Green, K.M., \& Slevin, D.P. (2006). Strategic process effects on the entrepreneurial orientation-sales growth rate relationship. Entrepreneurship Theory \& Practice, 30, 57-81.

Dayan, M., \& Di Benedetto, C. (2011). Team intuition as a continuum construct and new product creativity: The role of environmental turbulence, team experience, and stress. Research Policy, 40, 276-286.

De Clercq, D., \& Belausteguigoitia, I. (2017). Reducing the harmful effect of role ambiguity on turnover intentions: The roles of innovation propensity, goodwill trust, and procedural justice. Personnel Review, 46, 1046-1069.

De Clercq, D., Rahman, Z.M., \& Belausteguigoitia, I. (2017). Task conflict and employee creativity: The critical roles of learning orientation and goal congruence. Human Resource Management, 56, 93-109.

De Clercq, D., Thongpapanl, N., \& Dimov, D. (2009). When good conflict gets better and bad conflict becomes worse: The role of social capital in the conflict-innovation relationship. Journal of the Academy of Marketing Science, 37, 283-297.

Eisenberg, N., and Fabes, R.A. (1992). Emotion, regulation, and the development of social competence. In M.S. Clark (Ed.), Emotion and social behavior (Vol. 14, pp. 119-150). Newbury Park, CA: Sage.

Fischer, S., Frese, M., Mertins, J.C., Hardt, J.V., Flock, T., et al. (2014). Climate for personal initiative and radical and incremental innovation in firms: A validation study. Journal of Enterprising Culture, 22, 91-109.

Garcia, P.R.J.M., Bordia, P., Restubog, S.L.D, \& Caines, V. (2018). Sleeping with a broken promise: The moderating role of generativity concerns in the relationship between psychological contract breach and insomnia among older workers. Journal of Organizational Behavior, 39, 326-338.

Gerbing, D.W., \& Anderson, J.C. (1988). An updated paradigm for scale development incorporating unidimensionality and its assessment. Journal of Marketing Research 25,186192.

Gong, Y., Huang, J.-C., \& Farh, J.-L. (2009). Employee learning orientation, transformational leadership, and employee creativity: The mediating role of employee creative self-efficacy. Academy of Management Journal, 52, 765-778. 
Gratz, K.L., \& Roemer, L. (2004). Multidimensional assessment of emotion regulation and dysregulation: development, factor structure, and initial validation of the difficulties in emotion regulation scale. Journal of Psychopathology and Behavioral Assessment, 26, 41-54.

Gross, J.J. (1998). The emerging field of emotion regulation: An integrative review. Review of General Psychology, 2, 271-299.

Harrison, T.R., Hopeck, P., Desrayaud, M., and Imboden, K. (2013). The relationship between conflict, anticipatory procedural justice, and design with intensions to use ombudsman processes. International Journal of Conflict Management, 24, 56-72.

Hill, R., Morganson, V. J., Matthews, R.A., \& Atkinson, T. (2016). LMX, breach perceptions, work-family conflict, and well-being: A mediational model. Journal of Psychology: Interdisciplinary \& Applied, 150, 132-149

Hobfoll, S.E. (1989). Conservation of resources: A new attempt at conceptualizing stress. American Psychologist, 44: 513-524.

Hobfoll, S.E. (2001). The influence of culture, community, and the nested-self in the stress process: Advancing conservation of resource theory. Applied Psychology: An International Review, 50, 337-369.

Hobfoll, S.E. (2002). Social and psychological resources and adaptation. Review of General Psychology, 6, 307-324.

Hobfoll, S.E., \& Shirom, A. (2000). Conservation of resources theory: Applications to stress and management in the workplace. In R.T. Golembiewski (Ed.), Handbook of organization behavior (2d ed., pp. 57-81). New York: Dekker.

Hocevar, D. (1981). Measurement of creativity: Review and critique. Journal of Personality Assessment, 45, 450-464.

Hofstede, G.H., Hofstede, G.J., \& Minkov, M. (2010). Cultures and organizations: Software of the mind. Intercultural cooperation and its importance for survival ( $3^{\text {rd }} \mathrm{ed}$.). New York: McGraw-Hill.

Jamil, A., Raja, U, \& Darr, W. (2013). Psychological contract types as moderator in the breachviolation and violation-burnout relationships. Journal of Psychology: Interdisciplinary \& Applied, 150, 147, 491-515.

Janssen, O. (2000). Job demands, perceptions of effort-reward fairness, and innovative work behavior. Journal of Occupational and Organizational Psychology, 73, 287-302.

Janssen, O. (2001). Fairness perceptions as a moderator in the curvilinear relationships between job demands, and job performance and job satisfaction. Academy of Management Journal, 44, 1039-1050.

Jiang, J.Y., Zhang, X., \& Tjosvold, D. (2013). Emotion regulation as a boundary condition of the relationship between team conflict and performance: A multi-level examination. Journal of Organizational Behavior, 34, 714-734.

José, H., Parreira, P., Thorson, J.A., \& Allwardt, D. (2007). A factor-analytic study of the multidimensional sense of humor scale with a Portuguese sample. North American Journal of Psychology, 9, 595-610.

Kalliny, M., Cruthirds, K.W., \& Minor, M.S. (2006). Differences between American, Egyptian and Lebanese humor styles: Implications for international management. International Journal of Cross Cultural Management, 6, 121-134.

Kaufman, J. C., \& Baer, J. (2004). Sure, I'm creative - but not in math! Self-reported creativity in diverse domains. Empirical Studies of the Arts, 22, 143-155. 
Kraak, J.M., Lunardo, R., Herrbach, O., \& Durrieu, F. (2017). Promises to employees matter, self-identity too: Effects of psychological contract breach and older worker identity on violation and turnover intentions. Journal of Business Research, 70, 108-117.

Lahiri, S., Pérez-Nordtvedt, L., \& Renn, R.W. (2008). Will the new competitive landscape cause your firm's decline? It depends on your mindset. Business Horizons, 51, 311-320.

Lapointe, É., Vandenberghe, C., \& Boudrias, J.-S. (2013). Psychological contract breach, affective commitment to organization and supervisor, and newcomer adjustment: A threewave moderated mediation model. Journal of Vocational Behavior, 83, 528-538.

Lattin, J.M., Carroll, J.D., \& Green, P.E. (2003). Analyzing multivariate data. Belmont, CA: Thomson Brooks/Cole.

Lehmann-Willenbrock, N., \& Allen, J.A. (2014). How fun are your meetings? Investigating the relationship between humor patterns in team interactions and team performance. Journal of Applied Psychology, 99, 1278 - 1287.

Liang, J., Farh, C.I.C., \& Farh, J. (2012). Psychological antecedents of promotive and problemfocused voice: A two-wave examination. Academy of Management Journal, 55, 71-92.

Lumsden, C.J. (1999). Evolving creative minds: Stories and mechanisms. In R. J. Sternberg (Ed.), Handbook of creativity (pp. 153-168). New York: Cambridge University Press.

Lyttle, J. (2007). The judicious use and management of humor in the workplace. Business Horizons, 50, 239-245.

Mahajan, A., Bishop, J.W., \& Scott, D. (2012). Does trust in top management mediate top management communication, employee involvement and organizational commitment relationships? Journal of Managerial Issues, 24, 173-190.

Mesmer-Magnus, J., Glew, D.J., \& Chockalingam, V. (2012). A meta-analysis of positive humor in the workplace. Journal of Managerial Psychology, 27, 155-190.

Ng, T.W.H., \& Feldman, D.C. (2012). Employee voice behavior: a meta-analytic test of the conservation of resources framework. Journal of Organizational Behavior, 33, 216-234.

O’Boyle, E.H., Humphrey, R.H., Pollack, J.M., Hawver, T.H., \& Story, P.A. (2011). The relation between emotional intelligence and job performance: A meta-analysis. Journal of Organisational Behaviour, 10, 788-818.

Oldham, G. R., \& Cummings, A. (1996). Employee creativity: Personal and contextual factors at work. Academy of Management Journal, 39, 607-634.

Orvis, K.A., Dudley, N.M., \& Corlina, J.M. (2008). Conscientiousness and reactions to psychological contract breach: A longitudinal field study. Journal of Applied Psychology, 93, 1183-1193.

Oyserman, D., Coon, H.M., \& Kemmelmeier, M. (2002). Rethinking individualism and collectivism: Evaluation of theoretical assumptions and meta-analyses. Psychological Bulletin, 128, 3-72.

Parke, M.R., Seo, M.-G., \& Sherf, E.N. (2015). Regulating and facilitating: The role of emotional intelligence in maintaining and using positive affect for creativity. Journal of Applied Psychology, 100, 917-934.

Perko, K., Kinnunen, U., \& Feldt, T. (2017). Long-term profiles of work-related rumination associated with leadership, job demands, and exhaustion: A three-wave study. Work and Stress, 31, 395-420.

Phuong, T.-H. (2016). The moderating impacts of age and locus of control on the psychological contract breach-outcomes relationships: A Vietnam-Japan comparative study. International Journal of Business and Society, 17, 329-346. 
Podsakoff, P.M., \& Organ, D.W. (1986). Self-reports in organization research: Problems and prospects. Journal of Management, 12, 532-544.

Pooja, A.A., De Clercq, D., \& Belausteguigoitia, I. (2016). Job stressors and organizational citizenship behavior: The roles of organizational commitment and social interaction. Human Resource Development Quarterly, 27, 373-405.

Porter, M.E. (1996). What is strategy? Harvard Business Review, 75, 61-78.

Pouthier, V. (2017). Griping and joking as identification rituals and tools for engagement in cross-boundary team meetings. Organization Studies, 38, 753-774.

Preacher, K.J., \& Hayes, A.F. (2004). SPSS and SAS procedures for estimating indirect effects in simple mediation models. Behavior Research Methods, Instruments, \& Computers, 36, 717-731.

Priesemuth, M., \& Taylor, R.M. (2016). The more I want, the less I have left to give: The moderating role of psychological entitlement on the relationship between psychological contract violation, depressive mood states, and citizenship behavior. Journal of Organizational Behavior, 37, 967-982.

Quinn, R.W., Spreitzer, G.M., \& Lam, C.F. (2012). Building a sustainable model of human energy in organizations: Exploring the critical role of resources. Academy of Management Annals, 6, 337-396.

Raja, U., Johns, G., \& Ntalianis, F. (2004). The impact of personality on psychological contracts. Academy of Management Journal, 47, 350-367.

Rayton, B.A., \& Yalabik, Z.Y. (2014). Work engagement, psychological contract breach and job satisfaction. International Journal of Human Resource Management, 25, 2382-2400.

Restubog, S.L.D., Bordia, P., \& Bordia, S. (2011). Investigating the role of psychological contract breach on career success: Convergent evidence from two longitudinal studies. Journal of Vocational Behavior, 79, 428-437.

Restubog, S.L.D., Bordia, P., \& Tang, R.L. (2007). Behavioural outcomes of psychological contract breach in a non-western culture: The moderating role of equity sensitivity. British Journal of Management, 18, 376-386.

Restubog, S.L.D., Hornsey, M. J., Bordia, P., \& Esposo, S. R. (2008). Effects of psychological contract breach on organizational citizenship behaviour: Insights from the group value model. Journal of Management Studies, 45, 1377-1400.

Restubog, S.L.D., Zagenczyk, T.J., Bordia, P., Bordia, S., \& Chapman, G.J. (2015). If you wrong us, shall we not revenge? Moderating roles of self-control and perceived aggressive work culture in predicting responses to psychological contract breach. Journal of Management, 41, 1132-1154.

Robert, C., \& Yan, W. (2007). The case for developing new research on humor and culture in organizations: toward a higher grade of manure. Research in Personnel and Human Resources Management, 26, 205-267.

Robinson, S.L., \& Morrison, E.W. (2000). The development of psychological contract breach and violation: A longitudinal study. Journal of Organizational Behavior, 21, 525-546.

Robinson, S.L., \& Rousseau, D. M. (1994). Violating the psychological contract: Not the exception but the norm. Journal of Organizational Behavior, 15, 245-259.

Romero, E.J., \& Cruthirds, K.W. (2006). The use of humor in the workplace. Academy of Management Perspectives, 20, 58-69.

Rousseau, D. M. (1995). Psychological contracts in organizations: Understanding written and unwritten agreements. Thousand Oaks, CA: Sage. 
Ryan, R.M., \& Deci, E.L. (2000). Self-determination theory and the facilitation of intrinsic motivation, social development, and well-being. American Psychologist, 55(1): 68-78.

Shalley, C.E. (1991). Effects of productivity goals, creativity goals, and personal discretion on individual creativity. Journal of Applied Psychology, 76, 179-185.

Shalley, C.E., \& Gilson, L.L. (2004). What leaders need to know: A review of social and contextual factors that can foster or hinder creativity. Leadership Quarterly, 15, 33-53.

Shalley, C.E., Gilson, L. L., \& Blum, T. C. (2009). Interactive effects of growth need strength, work context, and job complexity on self-reported creative performance. Academy of Management Journal, 52, 489-505.

Shore, L.M., \& Tetrick, L.E. (1994). The psychological contract as an explanatory framework in the employment relationship. In C.L. Cooper, \& D.M. Rousseau (Eds.), Trends in organizational behavior (pp. 91-103). New York: Wiley.

Simons, T., \& Peterson, R.S. (2000). Task conflict and relationship conflict in top management teams: The pivotal role of intragroup trust. Journal of Applied Psychology, 83, 102-111. Smith, J.W., \& Khojasteh, M. (2014). Use of humor in the workplace. International Journal of Management \& Information Systems, 18.

Sonnenberg, M., Koene, B., \& Paauwe, J. (2011). Balancing HRM: the psychological contract of employees. Personnel Review, 40, 664-683.

Spector, P.E. (2006). Method variance in organizational research: Truth or urban legend? Organizational Research Methods, 9, 221-232.

Stephens, J. P., Heaphy, E. D., Carmeli, A., Spreitzer, G. M., \& Dutton, J. E. 2013. Relationship quality and virtuousness: Emotional carrying capacity as a source of individual and team resilience. Journal of Applied Behavioral Science, 49, 13-41.

Suazo, M.M. (2009). The mediating role of psychological contract violation on the relations between psychological contract breach and work-related attitudes and behaviors. Journal of Managerial Psychology, 24, 136-160.

Suazo, M.M., \& Stone-Romero, E.F. (2011). Implications of psychological contract breach. Journal of Managerial Psychology, 26, 366-382.

Sy, T., Tram, S., \& O'Hara, L.A., 2006. Relation of employee and manager emotional intelligence to job satisfaction and performance. Journal of Vocational Behavior, 68, 461-473.

Thorson, J., \& Powell, F (1993). Development and validation of a multidimensional sense of humor scale. Journal of Clinical Psychology, 49, 13-23.

Tomprou, M., Nikolaou, I., \& Vakola, M. (2012). Experiencing organizational change in Greece: the framework of psychological contract. International Journal of Human Resource Management, 23, 385-405.

Tse, H.H.M., \& Chiu, W.C.K. (2014). Transformational leadership and job performance: A social identity perspective. Journal of Business Research, 67, 2827-2835.

Vancouver, J.B., \& Schmitt, N.W. (1991). An exploratory examination of person organization fit: Organizational goal congruence. Personnel Psychology, 44, 333-352.

Wang, R., Chan, D.K.S., Goh, Y.W., Penfold, M., Harper, T., \& Weltewitz, T. (2018). Humor and workplace stress: A longitudinal comparison between Australian and Chinese employees. Asia Pacific Journal of Human Resources, 56, 175-195.

Yuan, F., \& Woodman, R. W. (2010). Innovative behavior in the workplace: The role of performance and image outcome expectations. Academy of Management Journal, 53, 323342. 
Zagenczyk, T.J., Gibney, R., Few, W.T., \& Scott, K.L. (2011). Psychological contracts and organizational identification: The mediating effect of perceived organizational support. Journal of Labor Research, 32, 254-281.

Zahra, S., \& Hayton, J.C. (2008). The effect of international venturing on firm performance: The moderating influence of absorptive capacity. Journal of Business Venturing, 23, 195-220.

Zhou, J., \& George, J. M. (2001). When job dissatisfaction leads to creativity: Encouraging the expression of voice. Academy of Management Journal, 44, 682-696.

Zhou, J., Shin, S. J., \& Canella, A. A., Jr. (2008). Employee self-perceived creativity after mergers and acquisitions: Interactive effects of threat-opportunity perception, access to resources, and support for creativity. Journal of Applied Behavioral Science, 44, 397-421. 
Figure 1: Conceptual model

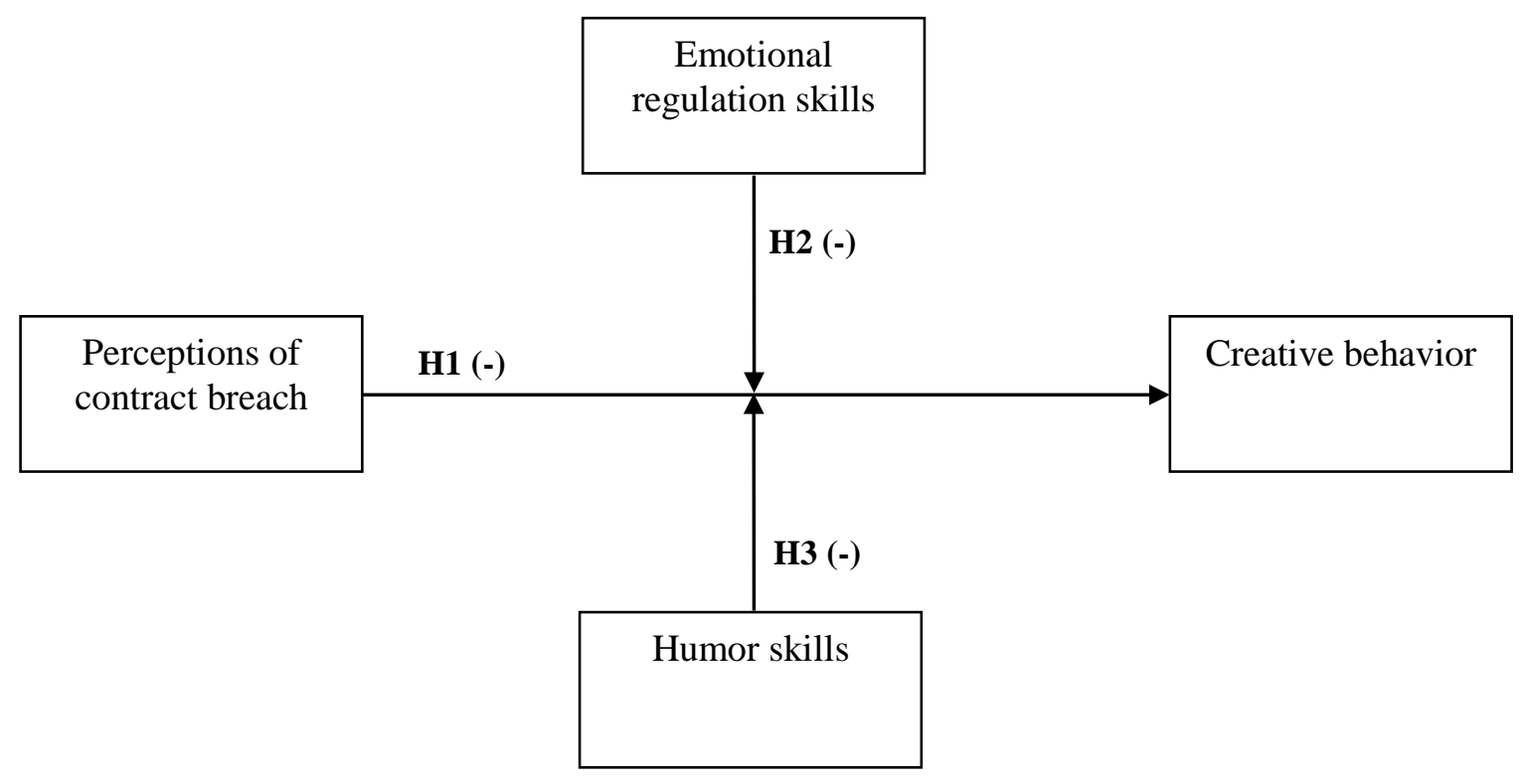


Figure 2: Moderating effect of emotional regulation skills on the relationship between perceptions of contract breach and creative behavior

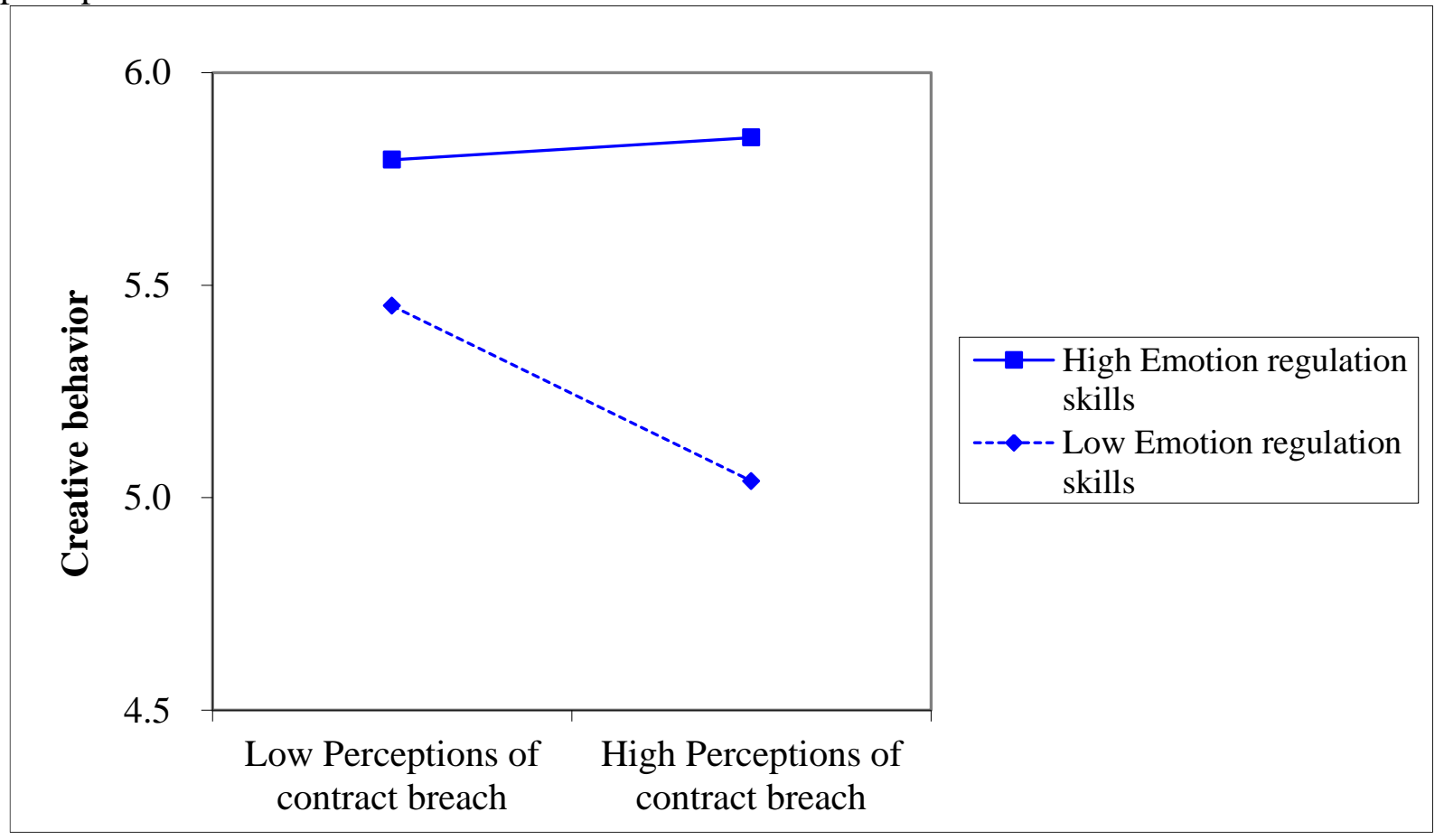

Figure 3: Moderating effect of humor skills on the relationship between perceptions of contract breach and creative behavior

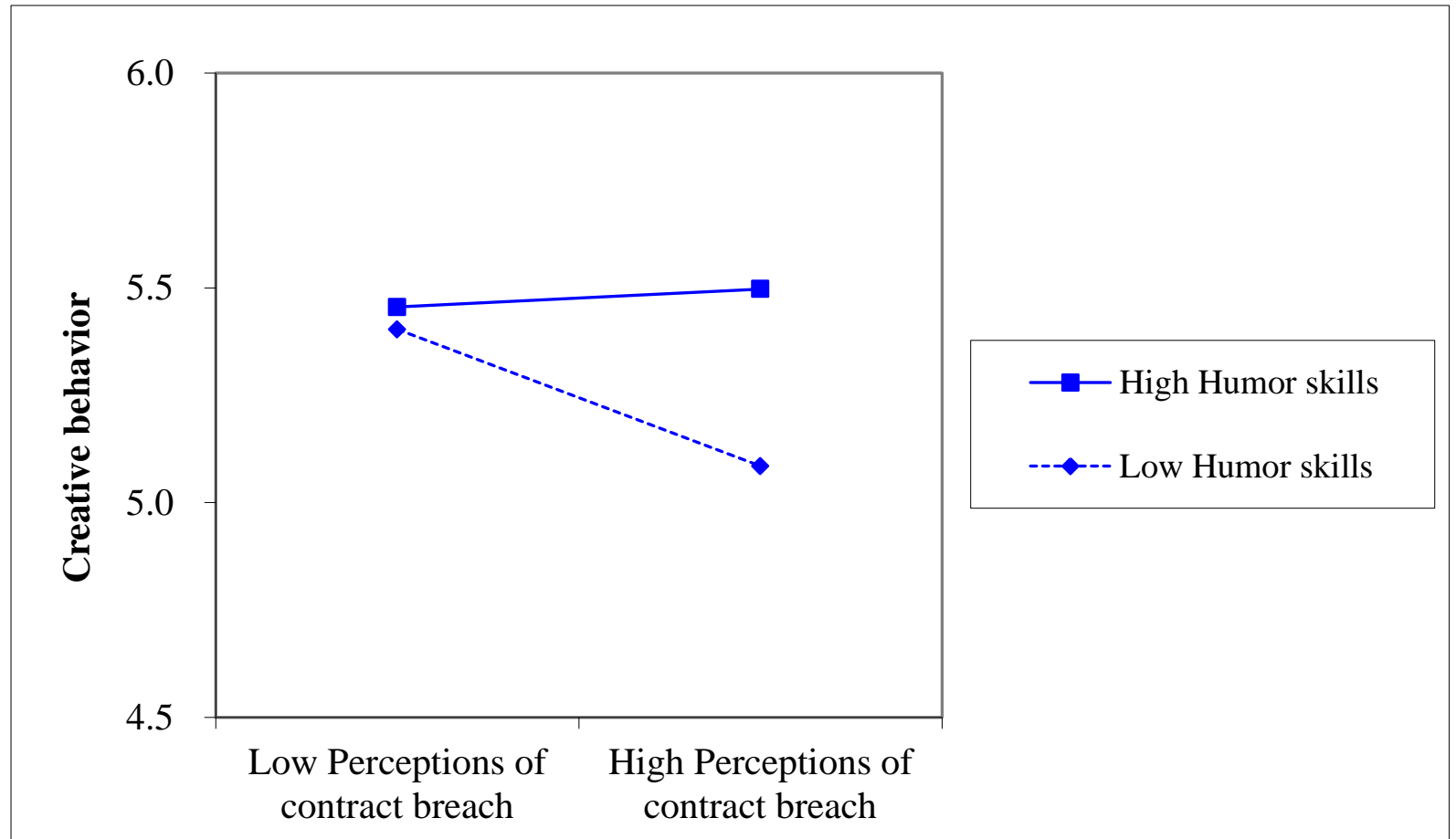


Table 1: Correlations and descriptive statistics

\begin{tabular}{|c|c|c|c|c|c|c|c|c|}
\hline & Mean & SD & 1 & 2 & 3 & 4 & 5 & 6 \\
\hline 1. Creative behavior & 5.36 & .99 & & & & & & \\
\hline 2. Perceptions of contract breach & 2.39 & 1.60 & $-.20 * *$ & & & & & \\
\hline 3. Emotional regulation skills & 5.63 & .93 & $.38 * *$ & $-.17 *$ & & & & \\
\hline 4. Humor skills & 5.44 & 1.16 & $.25 * *$ & -.13 & $.31 * *$ & & & \\
\hline 5. Gender $(1=$ female $)$ & .40 & .49 & -.14 & -.13 & $-.18^{*}$ & .06 & & \\
\hline 6. Organizational tenure & 3.18 & 1.54 & -.04 & .08 & -.10 & -.04 & -.11 & \\
\hline 7. Job level & 1.66 & .73 & $.15^{*}$ & .10 & -.02 & -.02 & $-.32 * *$ & $.22 * *$ \\
\hline
\end{tabular}

Notes: $\mathrm{N}=173$.

$* * p<.01 ; * p<.05$. 
Table 2: Regression results (dependent variable: creative behavior)

\begin{tabular}{|c|c|c|c|c|}
\hline & Model 1 & Model 2 & Model 3 & Model 4 \\
\hline Gender $(1=$ female $)$ & -.22 & -.14 & -.24 & -.18 \\
\hline Organizational tenure & -.05 & -.03 & -.02 & -.02 \\
\hline Job level & $.18^{+}$ & $.22 *$ & $.17^{+}$ & $.21 *$ \\
\hline $\mathrm{H}_{1}$ : Perceptions of contract breach & & $-.09 *$ & $-.09 *$ & -.07 \\
\hline Emotional regulation skills & & $.32 * * *$ & $.29 * * *$ & $.30 * * *$ \\
\hline Humor skills & & $.12 *$ & $.11^{+}$ & $.12^{+}$ \\
\hline $\begin{array}{l}\mathrm{H}_{2} \text { : Perceptions of contract breach } \times \text { emotional } \\
\text { regulation skills }\end{array}$ & & & $.12 * *$ & \\
\hline $\mathrm{H}_{3}$ : Perceptions of contract breach $\times$ humor skills & & & & $.09 * *$ \\
\hline $\begin{array}{r}\mathrm{R}^{2} \\
\mathrm{R}^{2} \text { change }\end{array}$ & .04 & $\begin{array}{c}.22 \\
.18^{* * * *} \\
\end{array}$ & $\begin{array}{l}.26 \\
.04 * * \\
\end{array}$ & $\begin{array}{c}.25 \\
.03 * * \\
\end{array}$ \\
\hline
\end{tabular}

Notes: $\mathrm{N}=173$. Unstandardized regression coefficients are reported.

$* * * p<.001 ; * * p<.01 ; * p<.05 ;{ }^{+} p<.10$ (two-tailed tests). 